\title{
Technology as Both a Facilitator of and Response to Youth Intimate Partner Violence: Perspectives from Advocates in the Global-South
}

\author{
Gisella Lopes Gomes Pinto Ferreira
}

\begin{abstract}
Much of the research on intimate partner violence focuses on adults, and little of it emanates from the Global-South. The study reported upon in this chapter is aimed at addressing these gaps. Adopting a Southern Feminist Framework, it discusses findings from interviews with Brasilian and Australian advocates working on prevention of youth IPV. Participants from both countries noted disturbing instances of digital coercive control among the youth with whom they work, as well as underlying factors such as genderbased discrimination that simultaneously contribute to the prevalence of such behaviors, as well as their normalization among young people. However, they also emphasized the positive role that technology can play in distributing educational programming that reaches young people where they are and circumvents conservative agendas that in some cases keep education about gender discrimination and healthy relationships out of schools.
\end{abstract}

Keywords: Technology-facilitated abuse and stalking; young people;

Global-South; Brasil; Australia; prevention

\section{Introduction}

Scholarly and government research suggests that, generally, young people are the age cohort most susceptible to intimate partner violence (IPV) but lack

The Emerald International Handbook of Technology-Facilitated Violence and Abuse, 427-446 Copyright $@ 2021$ Gisella Lopes Gomes Pinto Ferreira

Published by Emerald Publishing Limited. This chapter is published under the Creative

Commons Attribution (CC BY 4.0) licence. Anyone may reproduce, distribute, translate and create derivative works of these chapters (for both commercial and non-commercial purposes), subject to full attribution to the original publication and authors. The full terms of this licence may be seen at http://creativecommons.org/licences/by/4.0/legalcode.

doi:10.1108/978-1-83982-848-520211032 
understanding of how IPV manifests and can be addressed (Australian Institute of Health and Welfare, 2018; Fórum Brasileiro de Segurança Pública, 2019; Murta et al., 2019). Normalization or naturalization of abuse can also be a barrier (Murta et al., 2019). There are profound health-related and social impacts for young people because this time of life is often when people engage in their first intimate relationship, and prior experience of abuse can affect later relationships (Murta et al., 2019). Evidence suggests that the presence of technology in relationships is increasing, and with it the use of technology to enact IPV (Politoff et al., 2019; UN General Assembly, 2018). In this vein, King-Ries (2011) claims that teenagers are particularly vulnerable, as they "pervasively use and incorporate technology in their intimate relationships" and so "tend to believe that what is happening [the abuse and stalking] to themselves and their peers is normal" (p. 155).

Given the role of technology in friendship networks and dating practices, the immediate and future consequences of youth IPV and young people's higher risk of this type of violence, it is imperative that we investigate how abuse and stalking are perpetrated using technology, which may also be a channel for preventing IPV. In this vein, it is fundamental to talk with advocates. Historically, advocates' and feminist movements' hard work prompted shifts in policy and prevention, yet they are often overlooked in academic studies (Flood, 2019; Harris, Dragiewicz, \& Woodlock, 2020). This chapter aims to address this gap in the literature by drawing on interviews conducted with Brasilian and Australian advocates. It adopts the concept of Digital Coercive Control (DCC) (defined as "the use of devices and digital media to stalk, harass, threaten and abuse partners or expartners [Harris \& Woodlock, 2019, p. 533])" to examine how IPV is perpetrated among youth groups based on the perspectives of the advocates interviewed. In their research on DCC, Harris and Woodlock (2019) use Stark's work on coercive control (2007) focused on adults. However, this concept is also relevant in the youth context because it highlights how this violence is enacted, and its motivation and consequences (Harris \& Woodlock, 2019; Taylor, Murphy-Graham, \& Lauro, 2019). This chapter also explores how technology has been used by advocates to prevent youth DCC, and the benefits and limitations of such.

The chapter begins with an overview of previous research relating to youth and IPV before turning to discuss the methodology used in my study of advocates in Brasil $^{1}$ and Australia. It then discusses the results of my study in light of previous research findings before concluding with suggestions for future research that focuses on gaining a better understanding of and preventing technology-facilitated IPV (TFIPV) among youth.

\section{Previous Research}

Young people are the age group most vulnerable to IPV; however, most research to date has targeted adult IPV (Taylor et al., 2017). The existing research on youth IPV comes predominantly from North America (Murta, dos Santos, Martins, \& de Oliveira, 2013; Rodríguez Domínguez, Pérez-Moreno, \& Durán, 2020). There is a relatively small body of literature in the Global-South. In Brasil, these studies are mostly concerned with the prevalence of youth IPV, and they frequently do not mention youth experiences of DCC (Beserra et al., 2015). There are a few 
exceptions including the work of Oliveira, Assis, Njaine, and Oliveira (2011), Instituto Avon/Data Popular (2014), Énois I Inteligência Jovem, Instituto Vladimir Herzog, \& Instituto Patrícia Galvão (2015) and more recently Campeiz (2018) and Taylor et al. (2017, 2019). There are a few studies in Brasil focused on the prevention of IPV and gender-based violence more broadly among youth, for example, the work of Murta et al. (2013, 2019, 2020), Taylor et al. (2017) and Viza, Sartori, \& Zanello (2017). In Australia, youth IPV was addressed in prevention research, including the work of Flood (2019) guiding the engagement of men and boys for preventing violence against women and girls. Additional examples include the research of Pascua, Khokhar, Saeed, Uwineza, and Taukolo (2019) and Struthers, Parmenter, and Tilbury (2019) focused on preventing violence in relationships through peer education, and "also referring to related programs such as sexual violence prevention programs, image-based abuse, and on-line abuse prevention programs" (Pascua et al., 2019, p. 2); The Line (2017) social marketing campaigns targeting young people and promoting healthy, respectful, and consensual relationships; Senior, Helmer and Chenhall's (2017) work on Indigenous young women's perceptions of IPV; Mackenzie and Mackay's report on young country women's perceptions of IPV (2019); and research focused on youth attitudes toward violence against women (Politoff et al., 2019).

While there are particularities based on country, region, and group, the existing research demonstrates that in general, technology plays a crucial role in youth intimate relationships as it is heavily used by youth to engage in relationships, and also to perpetrate DCC, including tracking and monitoring their partners and their digital accounts. These controlling behaviors are often mistaken by youth as signs of love, caring, and jealousy (Campeiz, 2018; Taylor et al., 2017). Brasilian and Australian research indicates that often other forms of online violence such as image-based abuse (IBA) accompany DCC, particularly after the end (or the attempt to end) a relationship (Henry, McGlynn, Flynn, Johnson, Powell, \& Scott, 2020; Henry, Powell, \& Flynn, 2017; Oliveira et al., 2011). The threat of IBA was also referred to as a means used by boys to force girls to remain in a relationship (Oliveira et al., 2011). Furthermore, the co-occurrence of family violence and IPV was also noted, as well as the fact that previous experience of abuse during childhood and adolescence can be a predictor of experiencing IPV in adult life too (Taylor et al., 2017; Ávila, 2017).

Brasilian and Australian studies highlight that young people face barriers to help-seeking, feeling ashamed, or lacking knowledge about support services (Soares, Lopes, \& Njaine, 2013; Tarzia, Iyer, Thrower, \& Hegarty, 2017). In this context, preventative use of technology can deliver useful widespread outcomes, by providing information and support in platforms where youth anonymity is ensured and free of judgment (Tarzia et al., 2017). Yet, there is limited research focused on the prevention of youth IPV via technological means (Tarzia et al., 2017). Many of the existing Brasilian and Australian prevention initiatives are face-to-face and based in schools which are often regarded as more effective (Flood, 2019). However, a few technology-based prevention initiatives have been documented. These include the construction of websites and a computer-tailored intervention to prevent youth IPV (Murta et al., 2020; Woodlock, 2017), chatbots 
to raise awareness about sexting and IBA among youth (UNICEF, 2019), and social marketing campaigns (The Line, 2017). There are other initiatives involving artificial intelligence, like the chatbots MAIA (Microsoft News Center Brasil, 2020) and Isa.bot (Cosmobots, n.d). These chatbots were launched in 2020 and 2019, respectively, which might explain the lack of published research regarding their development. A number of authors have recognized the potential of technology for preventing youth IPV and stressed the importance of engaging with young people themselves to develop initiatives designed to address their needs (Murta et al., 2020).

\section{Methodology}

\section{Southern Feminist Framework}

To date, the majority of the research on the prevention of youth IPV comes from North America (Daff, Mcewan, \& Luebbers, 2018; Murta et al., 2013). Thus, much of the global economy of knowledge in this area is imposed by the metropole (North) onto the periphery (South), disregarding the differences between these geographic areas and restricting the potential of "possible projects of knowledge" (Connell, 2014, p. 216). This chapter uses southern theory (Connell, 2007) and southern criminology (Carrington, Hogg, \& Sozzo, 2016) to address this knowledge deficit by drawing upon interviews with key advocates from Australia and Brasil who are engaged in the prevention of youth IPV. Advocates are the key responders to IPV, and their work has made IPV visible to the public; yet they are often overlooked in research (Harris et al., 2020). This chapter contributes toward filling this gap by giving voice to advocates from Brasil and Australia - countries that, despite their differences, share a violent history of colonialism, geological formation, geographic location, and a significant university system (Connell, Pearse, Collyer, Maia, \& Morrell, 2018) being part of what Connell (2013) refers to as the Southern tier. It acknowledges the need to include voices from the GlobalSouth, and thereby to democratize the production of knowledge and redress the Anglo-Saxon dominance of language (Carrington et al., 2016; Faraldo-Cabana, 2018).

The southern feminist framework combines southern criminology (Carrington et al., 2016) with a feminist research methodology (Bandeira, 2014). Gender inequality is a central focus of feminist research methodology. Considerable research suggests that heterosexual IPV is gendered, with women disproportionately represented as victim/survivors and men as perpetrators (Bancroft, 2002; FitzGibbon, Walklate, McCulloch, \& Maher, 2018). Research suggesting symmetry between the sexes in youth IPV (e.g., Strauss, 2004; Wolfe et al., 2001) has been criticized for using methods that fail to capture the violent context, dynamics of power and control, and acts of self-defense typically present in IPV (DeKeseredy \& Schwartz, 1998; Dobash \& Dobash, 1995), and for failing to take into account youth experiences with IPV (Daff et al., 2018; Minayo, Assis, \& Njaine, 2011). The United Nations Broadband Commission (2015) highlighted that young women aged 18-24 years are at heightened risk of exposure to all forms of TFVA, which 
supports a gendered understanding of young women's and girls' experiences of DCC. Furthermore, an intersectional lens is needed to fully comprehend youth IPV, encompassing age, class, race, ethnicity, and colonialism along with gender. While some dynamics of IPV in heterosexual relationships can apply to same-sex relationships, the latter has unique features which deserve attention, but are not the focus of this study (Bancroft, 2002; Our Watch, 2017).

\section{Methodology}

This qualitative and exploratory research draws from 14 interviews conducted with Brasilian advocates between June and July 2019 and five interviews conducted with Australian advocates between July 2019 and February 2020 to answer the following research questions: how is technology used to perpetrate abuse and stalking in young people aged 12-18 and how it can be used to address youth IPV from an advocate's perspective? Ethics approval was granted by the QUT Human Research Ethics Advisory Team (No. 1900000344). Participants were offered anonymity. Although most agreed to be identified, to protect their confidentiality, as well as the confidentiality of the youth they serve, all are referred to without identifying information in this chapter.

The greater number of Brasilian advocates (14) compared to Australian advocates (5) in the study helps to redress the over-representation of Australian advocates in existing related research. The participants were selected using purposive and snowball sampling which targeted advocates from peak organizations involved in youth IPV prevention in both countries. This sampling strategy was chosen to ensure that the most relevant participants were included, resulting in rich data and outcomes. Of the 14 participants from Brasil, nine were involved in the legal/justice sector, two were researchers/consultants, and three worked for anti-violence organizations. Of the five participants from Australia, four worked for anti-violence organizations, and one was a researcher.

All interviews were recorded and transcribed, and the transcripts were examined using thematic analysis. This procedure involved categorizing the emerging themes from my reflective journals and tables of data and importing the interviews into NVivo for further analysis and coding (Bazeley \& Jackson, 2013; Bryman, 2016).

Focusing on the perspectives of Brasilian and Australian advocates involved in youth IPV prevention helps to fill the gap in evidence from the Global-South and contributes to knowledge in the relatively new and understudied area of TFIPV among youth. Although the study did not engage with young people to gain their firsthand perspectives, the participating advocates' direct work with youth and/or in IPV prevention among youth offers rich insights relevant to TFIPV among youth and its prevention. Furthermore, these advocates may be in a better position to identify and report IPV than young people for whom IPV may be normalized (King-Ries, 2011). Thus, it provides relevant perspectives about youth experiences of TFIPV and technology use in prevention from key responders' 
eyes. As a qualitative study of key informants, while the results reported here are informative, they are not generalizable.

\section{Results and Discussion}

\section{Brasilian and Australian Landscapes of Digital Coercive Control}

Youth (15-24 years) are globally the most connected cohort group, as $71 \%$ are online (UNICEF, 2017). Most participants in this study agreed with the literature from the Global-South that young people are particularly vulnerable to DCC because this is a formative time when they are often engaging in their first intimate relationships and developing an identity (Politoff et al., 2019). Participants outlined behaviors that are covered by the DCC concept, including IBA and controlling behaviors. The majority of advocates raised concerns about the practice of and responses to sexting in youth intimate relationships. While most participants indicated that in their experience girls are at higher risk of IBA, this chapter focuses on the distinct forms of DCC described by participants, as research is scarce in this field. These include the use of technology by young people to exert power and control, as well as patterns of violence such as stalking.

Politoff et al. (2019) identified that, overall, young Australians (aged 16-24 years) understand that domestic violence encompasses physical and non-physical forms of violence, but that young men have less understanding of non-physical forms than do young women. Their data reveal that $79 \%$ of young men and $93 \%$ of young women in Australia identified "repeatedly keeps track of location, calls or activities through a mobile phone or other devices without consent" (stalking) as forms of violence (Politoff et al., 2019, pp. 19-20). By contrast, Énois et al.'s 2015 study indicates that, in Brasil, 55\% of girls aged 14-24 years had experienced their male partners checking - or trying to check - their phones, social media, and email; yet only $64 \%$ of these respondents identified this controlling behavior as a violent act. While these studies seem to suggest that Australian youth more readily identify controlling behaviors as abusive than do young Brasilians, there may be other explanations for the difference in results. The most prominent difference between the Brasilian and Australian evidence may be that the latter has often focused on youth knowledge of and attitudes toward gender-based violence against women (Politoff et al., 2019), while the former has focused on prevalence and examining young people's personal experiences of IPV (Énois et al., 2015; Instituto Avon/Data Popular, 2014). Therefore, it is not possible to conclude from these studies whether there is a significant difference between the overall understanding of violence among youth from both countries, or if in general young people might be downplaying these violent acts when they are the targets of them.

Overall, young Australians seem to identify digital controlling behaviors as a form of domestic violence; yet recent data highlights a decline in the understanding of domestic violence as gendered among young people compared to data from previous years (Politoff et al., 2019). One of my Australian participants who was from an anti-violence organization expressed their concern over this evidence: 
we're really concerned with [the data] in Australia that shows up for young people and adults is that the understanding that domestic violence is gendered is reducing. So, less people are understanding [that] domestic violence is most regularly perpetrated by men. At the same time that more people are more knowledgeable about the types of violence.

A similar trend can be seen in Brasil. Results from a study by the Instituto Avon/Data Popular (2014) highlighted that $96 \%$ of young Brasilians are against machismo. However, one participant from the Brasilian legal sector noted that many of these young people affirmed machista belief ${ }^{2}$ in their intimate relationships by perpetrating and normalizing a wide range of DCC behaviors, including tracking their partners through mobile phones and social media. This evidence from both countries raises key concerns, as denying and normalizing the drivers of gender-based violence create a barrier to effective prevention of such violence.

Many of my participants suggested that young people in Brasil often normalize monitoring, tracking, and stalking via mobile devices, primarily using applications like WhatsApp, and social media such as Instagram, Facebook, and Snapchat. They also conveyed their concern about the speed and level of use of WhatsApp among young Brasilians. Several times participants reported this application as a means used by boys to monitor/track their girlfriends through messages or video calls, demanding that their partners show them where they are and who they are with - behaviors explicitly demonstrative of patterns of power and control according to my participants, but not according to young people themselves. Access to a partner's mobile device and accounts without the partner's consent or knowledge through WhatsApp Web and hidden applications that permit the perpetrator to find their partner's location, listen to them and visualize their steps were also discussed in the interviews.

In contrast, two participants from the Australian anti-violence sector noted that in their experience, the use of WhatsApp is not very popular among young Australians, with its use primarily limited to communications with family overseas or workgroups. One of these advocates explained that Facebook, Instagram, Snapchat, Twitter, and YouTube are the most frequently used social media by young people in Australia - platforms also mentioned by the Brasilian advocates. Another Australian participant from the anti-violence sector expressed the view that apps like Snapchat can facilitate stalking as they have a "feature that automatically showed your location to people that use them." Both an Australian anti-violence sector participant and a Brasilian legal sector participant conveyed their impression that Facebook was not as popular as it had once been among youth in both countries. These observations contrasted with the Office of the eSafety Commissioner (2018) report indicating that Facebook was one of the most used platforms by Australian teens (aged 13-17 years). The data for the eSafety Commissioner report was collected in 2017, and the rapid development of technologies and changes in youth preferences might be reflected in the perspectives of my participants, indicating that Facebook is less popular now compared to 2017. 


\section{Gisella Lopes Gomes Pinto Ferreira}

The digital era fosters a culture of surveillance, inviting us all to control and to be controlled. As a result, some have argued that greater control might be "normative" in young people's relationships (Flach \& Deslandes, 2019; Harris \& Woodlock, 2019). In this regard, a recent study by Flach and Deslandes (2019) identified 40 applications designed to enable people to monitor their partners within Android and iOS operating systems. These authors' discourse analysis of these applications revealed the same dichotomy identified by the literature and by 12 of the 14 participants in this study, which equates tracking and control with caring and love. In this vein, Taylor et al. (2019) argue that controlling behaviors via technological means is present in the intimate relationships of most young Brasilians and that their overt use might indicate "collaboration" between partners as a strategy to prevent escalation of conflicts involving fears of infidelity and jealousy. In keeping with this analysis, one Brasilian participant from the legal sector emphasized that a common practice among young Brasilians is to create a shared account on social media as soon as they start dating as a way to keep track of each other (see also Campeiz, 2018). This participant explained that at first glance, this practice reflects an understanding of reciprocal control. However, she emphasized that it is commonly a means by which boys exert control over girls. Similarly, eight other participants from both countries highlighted their impressions that male partners often perpetrate DCC against their female partners. Three Brasilian participants also reported hearing of instances when boys had promised to give their girlfriend their password, but then did not; or sometimes where boys kept their contacts in hidden folders or outside the platforms their female partners could access.

The scarcity of examples of healthier relationships might hinder young people's identification of what is acceptable or not (Taylor et al., 2019). Taylor et al. (2019) indicate that, while many young Brasilians do not identify control as abuse, they often said they did not like it. There is limited research on how young people might be developing unhealthy technological norms within their intimate relationships and whether and how these norms might be perceived as distinct from the behaviors understood as truly abusive (Harris \& Woodlock, 2019). While this area requires further investigation, participants in my study saw digital controlling behaviors as problematic. One Australian participant from an antiviolence organization, for example, noted that technology "can increase the frequency and intensity of violence in some ways (...) [and] the stalking, and the harassment, and the mind games." Two other Brasilian participants from the legal sector further noted that such behaviors can sometimes escalate into physical violence and femicide, which is consistent with research findings relating to adults (Harris \& Woodlock, 2019; Taylor et al., 2019). Furthermore, three Brasilian participants identified as an aggravating factor the fact that digital technologies make the abuse and violence omnipresent. What Harris and Woodlock (2019) characterized as the spaceless nature of DCC, one Brasilian legal sector participant described as giving perpetrators "an almost totalitarian control of others' life and privacy space."

Both my Brasilian and Australian participants emphasized the significance of society's rigid gender stereotypes that normalize male control and female 
submission, as well as the understanding of DCC as a reflection of jealousy and therefore acceptable. Furthermore, five Brasilian participants expressed the view that the media also plays a crucial role in reinforcing these stereotypes by romanticizing control and stalking as desirable and positive signs within a relationship, increasing the tolerance of DCC and therefore the harm inflicted on girls who experience it. Participants from both countries expressed the view that this normalization blurs the line between what is acceptable and what is abusive, highlighting the need for greater attention on prevention initiatives. Their views in this regard are aligned with research findings such as that of Taylor and colleagues (2019). In this vein, one Australian participant from the anti-violence sector explained that education plays a fundamental role in prevention:

It's definitely crucial that young people are taught, from a young age, what is acceptable and what isn't acceptable. What crosses the line and is harmful, because sometimes it isn't just that easy in say —in black and white. Sometimes it's very grey.

While violence, abuse, and stalking have been enacted via digital technology, my participants highlighted that such technology can also be used to prevent youth IPV. The next section explores participants' perspectives on the use of technology to prevent violence, examining its potential benefits and limitations.

\section{Preventing Youth Intimate Partner Violence through Technology in the Global-South: Benefits and Challenges}

Participants argued that technology could be used as a means to educate, prevent, and respond to youth IPV, by spreading a message of gender equality and respectful relationships. Most participants indicated that they use social media, websites, and/or online games not only to promote their initiatives and research but also to raise awareness and engage young people (see also, for example, R4Respect, Pascua et al., 2019; Struthers et al., 2019). The broad reach to young people was my participants' most cited advantage of using technology for prevention, considering the high use of technology by youth and the ease of updating and adapting digital content (see also Murta et al., 2020; Tarzia et al., 2017). One Australian participant highlighted these advantages:

we can reach teenagers where they are. So, the fact that we can advertise, for example, in an online gaming platform, that that's where young men are, is really useful. Because we know that a lot of young people, but particularly young men, don't seek out this information.

This participant observed that technology "allows you to speak directly to young people without a mediator in between." This implies a major benefit: that reaching young people in digital spaces overcomes the obstacles faced in trying to 
reach them in other spaces, such as schools (in Brasil) or through certain digital platforms (in Australia) to which advocates often face barriers in gaining access. For example, one participant noted that in Australia, because the subject of IPV is considered sensitive, there are restrictions on any discussion of it on specific platforms, regardless of whether or not such discussion relates to prevention. Hence, the creation of advocates' own platforms is crucial. In this vein, The Line (2017) and other social marketing campaigns developed by Our Watch in Australia are seen as effective examples, with one participant from the research sector noting that they aim "to change the norms that shape dating violence, and that shape sexual violence among children and young people," and are well-tested and well-developed. At the same time, this participant believed that these campaigns could be improved as they do not pay "enough attention to how masculinity, for example, shapes some men's use of partner violence and dating violence."

In Brasil, two participants noted that the focus of public campaigns on IPV has predominantly been on encouraging women to report violence (see also Ávila, 2017) rather than on targeting the underlying causes of violence. One Brasilian participant from the consulting/research sector outlined that the police discourse was necessary in the past to encourage society to acknowledge violence against women as a serious issue. However, in her view, Brasilian society still does not understand the severity of this violence, and the justice system is not the only pathway for addressing gendered violence. She suggested, for example, that the Resource Center for Women in Situations of Violence could provide women with broader support, including information and psychological and social assistance. This observation is consistent with Tarzia et al.'s (2017) findings based on interviews with young Australian women, which affirmed that websites and applications should provide them not only with information regarding IPV but also how to contact support services and take further action. Consequently, campaigns should also encompass this approach to address young women's needs. The campaigns highlighted by the Brasilian and Australian participants differed regarding the moment at which intervention should take place - that is, before (Australia) or after the occurrence of the violence (Brasil). While all interventions are important, other research highlights the key importance of primary prevention (before the violence has happened) for young people (Flood, 2019).

Two of the Brasilian participants highlighted the development of artificial intelligence to assist young women in abusive relationships and enable them to discuss online violence, through chatbots like MAIA and Isa.bot. According to them, these bots play an essential role in support and prevention, given that girls and young women often do not seek help, and that these forums maintain their privacy and confidentiality and make no judgment about their story. However, it is important to check the privacy policies of technologies such as these to be certain about what is being done with user data. For example, according to the privacy policies of MAIA, the chatbot does not ask for any identifiable or personal information of users. It considers the users' anonymity fundamental, which is the reason why the content of the chat will not be stored (Microsoft News Center Brasil, 2020). By contrast, the Isa.bot policy indicates that the personal 
data provided by users can be collected and will be accessed exclusively by the team who provides support to women experiencing violence and might be used for research (Cosmobots, n.d).

The perspective that technology can be useful because it keeps users' anonymity and does not judge them is also found in the literature (Tarzia et al., 2017; UNICEF, 2019). In this regard, one Brasilian participant, along with Microsoft and other partners, developed MAIA (the Portuguese acronym for "my artificial intelligence friend"). Similarly, another Brasilian participant, in collaboration with her university research team developed a computer-tailored intervention hosted by a website called SOS Dating (Grupo de Estudos em Prevenção e Promoção de Saúde no Ciclo de Vida, n.d), which consists of four online sessions tailored to the participant's profile, including their sex, relationship type, knowledge of violence, and support network (see Murta et al., 2020). She believes that this initiative has the potential to be very successful because it provides customized advice to users rather than the one-size-fits-all advice generally offered on such platforms:

According to the literature on customized computerized interventions, they are more effective than interventions that are generalist, which is the same intervention for everyone. So, more identification, more memory and more behavior change would be expected. I don't know if we are going to achieve all this because the phenomenon is complex (...) But if we can at least get people to start looking for help, I will be more satisfied, it's already a result.

While one might argue that customization raises privacy concerns, this participant's research team ensures that all data is kept confidential and that only they will be able to use information shared by users, who will never be identified.

One Brasilian participant from the consulting sector highlighted that applications like Juntas (meaning "together" in Portuguese Geledés, 2014) could be seen as an important tool, particularly in the context of distrust of police (and perhaps in the context of a lack of knowledge about whether we should be trusting technology):

You can insert the contacts of some people you know, your sister, your friend, people close to you that you can contact in a situation of violence. It's also a nice thing because you're not relying only on the police service that might not answer to you, right?

Notwithstanding a certain level of community mistrust in the police, participants from both Brasil and Australia raised as important the availability and use of government-based applications for women who have been granted domestic violence orders (DVOs), as they provide a pathway to quickly contact the police via the application's emergency button in case of a threat. Several Brasilian states and the Federal District have adopted similar applications 
(Governo do Distrito Federal, 2017). One Brasilian participant suggested that this initiative is more useful for adult women, although young women can also access this service if they hold a DVO. While the restriction on the use of these government applications to DVO holders seems to be related to capacity building, this limitation excludes the majority of young and adult women experiencing IPV, as IPV is usually under-reported. Consequently, they will not have a DVO or access to the government application (Observatório da Mulher Contra a Violência et al., 2018).

Regarding the use of applications and bots, Brasilian participants flagged ethical and evaluation concerns. For example, one Brasilian participant outlined the risks these applications can pose to users, describing a situation in which, if these disguised applications that enable contact with police services are discovered by a woman/girl's abusive male partner, the violence can escalate dramatically. In relation to bots, this participant reflected:

we are talking about a robot giving advice, so one of the things we need to be sure of is if that advice and the result of this conversation of a girl interacting with a robot will not put her at risk (...) [and] how we can use [the] data and intelligence that the robot is accumulating without violating the girl's privacy, this is also something that we still don't have very clear (...) But it's happening (...) and we will not be able to stay very far from this, we will have to monitor it, but we are not doing this.

Most participants from both countries highlighted the lack of funding and human resources as primary barriers to the development of prevention strategies in general and those involving technology in particular. This obstacle impacts the effectiveness and duration of implementation of the strategies developed by advocates. In this regard, one Brasilian participant explained that she has been developing a computer-tailored intervention for almost five years and highlighted the complexity of this intervention, which demands qualitative studies and testing, revealing the amount of work and human and financial resources needed to implement this intervention. She also emphasized that the website would only be available for six months because this is the period for which they could pay for use of the software license, which is Dutch demonstrating the dependency on tools from the Global-North. Illustrating how limited funding can impact strategies, this participant outlined that if she had more funding, her team could work on developing its own national software, making this website available permanently. Similarly, a participant in Australia noted that

often funding for these sorts of initiatives is really short term. But we know that we need ongoing work in order to make real change. So the funding environment can be a real limitation or challenge to maximize [prevention initiatives]. 
While both the existing literature and my participants highlight the elevated use of the internet by young people, participants were also concerned about the needs of marginalized groups who have limited or no access to the internet or even mobile phones and of illiterate people - representing the digital divide. One Brasilian participant explained that applications connecting people with police services, for example, would not work in areas where no internet or mobile phones are available, which is a reality for many people in Brasil. Likewise, she noted that such applications would not work effectively in remote and rural areas of the country with the internet because by the time the police arrive at these areas, women and girls might already be dead. She outlined her concerns as follows:

I think it is a policy that we have to think about more because we adopt, there are a multitude of these applications. Apps are sold as easy and accessible, but is it accessible to whom? Who has 24-hour access to mobile internet? It's an expensive service, women who live on the outskirts who suffer violence cannot depend on an application on their cell phones, they don't have it all the time as we have it. So, we develop big projects and make huge publicity that they save lives, but we save the life of [small] parts [of the population] right? Of small parts of the population.

In relation to the above concerns, Brasilian and Australian participants emphasized the importance of developing strategies tailored to marginalized groups and the need to adopt multiple strategies to prevent youth IPV (see also Mackenzie \& Mackay, 2019). In this regard, it is fundamental to embrace an intersectional approach that recognizes all of the factors that, along with gender, increase the vulnerability of women to violence. Participants from Brasil noted, for example, how class and education can limit one's access to digital strategies, while other research shows how age, race, ethnicity, and colonialism place Black women in Brasil and Indigenous women in Australia at a higher risk of gendered violence (Carneiro, 2016; Our Watch, 2018). Hence, participants from both countries emphasized that it is vital to meet the needs of these groups and reach young people in the spaces in which they interact, beyond the internet.

In addition to access concerns, are concerns about whether and, if so, how well existing programming has been evaluated. With few exceptions, such as the program $\mathrm{H}$ evaluation of Promundo Brasil (Promundo, n.d), there is a significant lack of evaluation of primary prevention policies in Brasil. Indeed, the literature highlights that this field requires greater attention (Flood, 2019). One Australian participant suggested that Australian advocates who have more experience in this field and have produced evidence could assist Brasilian advocates with best practices for conducting evaluations of programs (see also Flood \& Kendrick, 2012; Our Watch, 2016; Pascua et al., 2019; Struthers et al., 2019). Nonetheless, despite significant efforts in the field of primary prevention in the Australian context, more work is needed in the evaluation space because from one Australian participant's perspective, program evaluations are usually 
short term, so you can only show very short-term change. Which basically means you can't track significant behaviour change, and you can't track perpetration.

Furthermore, one Australian participant noted that the evaluations conducted in Australia to date have mainly targeted school-based programs rather than initiatives involving technology. In a similar vein, Harris et al. (2020) highlighted that technology initiatives, such as chatbots, "are relatively new and are rarely evaluated." Thus, there is also a need to build evaluation tools to assess strategies based on digital technologies.

Both my Brasilian and Australian participants expressed an interest in, as one Brasilian participant put it, "how social media is used to create movements and communities." For example, four of the Brasilian participants spoke of how they have been engaging teenagers to produce short films and publish them on YouTube to raise awareness about violence against women and girls. By assessing the students' engagement with this initiative and the quality of the content and videos produced, these Brasilian participants perceived this strategy as successful and concluded that the benefits of using technology are thus evident. Some participants from both countries noted that the benefits overcome the setbacks because they can connect directly with young people as they are usually hyperconnected.

Finally, both Brasilian and Australian participants outlined how technology can be used to resist a gender backlash. In this vein, technology can reach young people who have not had access to school-based education programs around gender-based violence because of fundamentalist and conservative resistance from religious and political groups. In this regard, in both Australia and Brasil, participants reported that conservative agendas have been obstructing their work. In Brasil, one participant noted that some advocates have been avoiding talking about gender directly, particularly since this word was removed from the country's National Plan of Education in 2014, placing advocates, educators, and students at risk. In Australia, a feminist and gendered perspective seems to be stronger than in Brasil; however, resistance in the school setting was also noted by Australian participants. For example, one Australian participant described how a teacher, while discussing violence and healthy relationships in the classroom, told their students that "men experience domestic violence at the same rate as women" highlighting the types of barriers to addressing the problem, and the need to work with a whole-of-school approach. Messages about respectful relationships and gender equality need to be aligned and reinforced at all levels of society and in all spaces. In the meantime, technology could be a means to reach youth in both countries and to challenge the ongoing backlash.

\section{Conclusion}

This chapter has discussed advocates' perspectives on how technology is used by young Brasilians and Australians to enact DCC, and outlined the leading platforms used by youth to interact with each other and to perpetrate violence. It has 
also revealed how advocates in both countries have been incorporating technology into their own work and the work of others around the prevention of youth IPV, and considered the associated advantages and challenges. The main benefits of using technology to address youth IPV are the broad reach of technology, talking to young people where they are, and overcoming barriers imposed by conservative agendas and policies to access young people in physical and digital spaces, addressing youth barriers to help-seeking by preserving their anonymity, the ease to update and adapt the content, and the possibility to build and contact private networks in case of emergency (particularly important due to police mistrust). The main challenges identified are the lack of financial and human resources to create technology strategies, concerns of privacy, and lack of evaluation. The global production of knowledge is often driven by research undertaken in the English-speaking countries in the Global-North (Connell, 2007). This study challenges this global dominance. While the findings presented in this chapter are intended to inform the creation of preventive approaches to youth IPV in Brasil and Australia, the findings may well be relevant for other countries. There is no question that prevention initiatives should be tailored to each country according to the needs of its diverse population, but listening to contributions from countries which are often unheard and marginalized in the global economy of knowledge, can certainly generate new insights.

This study highlights the need to incorporate a gender perspective into initiatives to prevent youth IPV in both countries and to develop pathways to resist the gender backlash present - albeit to different degrees - in both countries.

A greater acknowledgment of youth IPV is needed, as most research targets adult IPV, and most research into youth DCC has focused on IBA rather than other forms of violence. Thus, future research should engage young people directly, exploring young people's needs and firsthand accounts of DCC experiences to inform prevention and evaluate prevention initiatives involving technology. Finally, countries need to prioritize IPV prevention and address the lack of funding in this area to allow advocates to develop medium-to long-term initiatives (and evaluations) that can promote real change around ending IPV against women and girls.

\section{Acknowledgment}

Thank you to Professor Jane Bailey and Sahana Sarkar for your feedback, and Dr Bridget Harris, Dr Laura Vitis, and Professor Kerry Carrington for their support and guidance on the chapter. Thank you to QUT Faculty of Law Research Scholarship for funding this research.

\section{Notes}

1. Inspired by Connell, Brasil is spelled with and "s" as in its national language, resisting Anglophone dominance (2014).

2. This refers to beliefs based on machismo "the belief that women should be subordinate to the needs and desires of their male partners, taking care of them, 
providing them pleasure (either as wives or partners or as approached in predatory fashion by men who would not consider marrying them), and bearing their children” (Wilson, 2014, p. 4).

\section{References}

Australian Institute of Health and Welfare. (2018). Family, domestic and sexual violence in Australia. Retrieved from https://www.aihw.gov.au/getmedia/d1a8d479a39a-48c1-bbe2-4b27c7a321e0/aihw-fdv-02.pdf.aspx?inline $=$ true

Ávila, T. P. d. (2017). Políticas públicas de prevenção primária à violência contra a mulher: Lições da experiência australiana. Revista Gênero, 17(2), 95-125. doi: 10.22409/rg.v17i2.944

Bancroft, L. (2002). Why does he do that?: Inside the minds of angry and controlling men. New York, NY: Putnam.

Bandeira, L. (2014). Violência de gênero: A construção de um campo teórico e de investigação. Sociedade e Estado, 29(2), 449-469. doi:10.1590/S0102-699220140002 00008

Bazeley, P., \& Jackson, K. (2013). Qualitative data analysis with NVivo. (2nd ed.). London: SAGE.

Beserra, M. A., Leitão, M. N. C., Fernandes, M. I. D., Scatena, L., Vidinha, T. S. S., Silva, L. M. P., \& Ferriane, M. G. C. (2015). Prevalence of dating violence among adolescents from Brazilian public schools of Recife/PE - Brazil. Revista de Enfermagem Referência, 7, 91-99. doi:10.12707/RIV15006

Bryman, A. (2016). Social research methods. (5th ed.). Oxford: Oxford University Press.

Campeiz, A. B. (2018). A violência nas relações de intimidade entre os adolescentes sob a perspectiva do Paradigma da Complexidade. Masters dissertation, Universidade de São Paulo.

Carneiro, S. (2016). Mulheres negras na educação: Desafios para a sociedade brasileira. In D. Carreira, C. Vianna, I. Leão, S. Unbehaum, Carneiro, \& S. Cavasin (Eds.), Gênero e educação: Fortalecendo uma agenda para as políticas educacionais (pp. 121-185). Rio de Janeiro: Henrich Boll. Retrieved from http://acaoeducativa.org.br/blog/publicacoes/porque-discutir-genero-na-escola/

Carrington, K., Hogg, R., \& Sozzo, M. (2016). Southern criminology. British Journal of Criminology, 56(1), 1-20. doi:10.1093/bjc/azv08

Connell, R. (2007). Southern theory: The global dynamics of knowledge in social science. Crows Nest: Allen \& Unwin.

Connell, R. (2013). The shores of the Southern Ocean: Steps toward a world sociology of modernity, with Australian examples. In S. Arjomand \& E. Reis (Eds.), Worlds of difference (pp. 58-72). Los Angeles, CA: SAGE. doi:10.4135/9781446288641.n4

Connell, R. (2014). Using southern theory: Decolonising social thought in theory, research and application. Planning Theory, 13(2), 210-223. doi:10.1177/1473095 213499216

Connell, R., Pearse, R., Collyer, F., Maia, J., \& Morrell, R. (2018). Re-making the global economy of knowledge: Do new fields of research change the structure of North-South relations? British Journal of Sociology, 69(3), 738-757. doi:10.1111/ 1468-4446.12294 
Cosmobots. (n.d.). ISA.bot. Retrieved from https://www.isabot.org/\#block-13769

Daff, E., Mcewan, T., \& Luebbers, S. (2018). Australian adolescents' experiences of aggression and abuse by intimate partners. Journal of Interpersonal Violence, 1-24. doi:10.1177/0886260518801936

DeKeseredy, W. S., \& Schwartz, M. D. (1998). Measuring the extent of woman abuse in intimate heterosexual relationships: A critique of the conflict tactics scales. Harrisburg, PA: US Department of Justice Violence Against Women Grants Office Electronic Resources.

Dobash, R., \& Dobash, R. (1995). Reflections on findings from the violence against women Survey. Canadian Journal of Criminology, 37(3), 457-504. Retrieved from http://search.proquest.com/docview/216100452/

Énois I Inteligência Jovem, Instituto Vladimir HerzogInstituto Patrícia Galvão. (2015). \#meninapodetudo: Machismo e violência contra a mulher. Retrieved from https:// dossies.agenciapatriciagalvao.org.br/dados-e-fontes/pesquisa/meninapodetudomachismo-e-violencia-contra-a-mulher-enois-inteligencia-joveminstituto-vladimirherzoginstituto-patricia-galvao-2015/

Faraldo-Cabana, P. (2018). Research excellence and Anglophone dominance: The case of law, criminology and social science. In K. Carrington, R. Hogg, \& M. Sozzo (Eds.), The Palgrave handbook of criminology and the Global South (pp. 163-181). Cham: Springer International Publishing. doi:10.1007/978-3-319-65021-0_9

Fitz-Gibbon, K., Walklate, S., McCulloch, J., \& Maher, J. (Eds.). (2018). Intimate partner violence, risk and security: Securing women's lives in a Global world (pp. 1-15). Oxon: Routledge. Retrieved from https://ebookcentral.proquest.com

Flach, R., \& Deslandes, S. (2019). Cyber dating abuse or proof of love? The use of apps for surveillance and control in affective-sexual relations. Cadernos de Saúde Pública, 35(1), e00060118. doi:10.1590/0102-311x00060118

Flood, M. (2019). Engaging men and boys in violence prevention. New York, NY: Palgrave Macmillan US. doi:10.1057/978-1-137-44208-6

Flood, M., \& Kendrick, V. (2012). LOVEBiTES: An evaluation of the LOVEBiTES and respectful relationships programs in a Sydney school. Wollongong: University of Wollongong. Retrieved from https://ro.uow.edu.au/cgi/viewcontent.cgi?article $=29$ 69\&context $=$ artspapers

Fórum Brasileiro de Segurança Pública. (2019). Visível e invisível - a vitimização de mulheres no Brasil. (2a edição). Retrieved from http://www.forumseguranca.org.br/ wp-content/uploads/2019/02/relatoriopesquisa-2019-v6.pdf

Geledés (2014). Juntas no enfrentamento à violência contra as mulheres. Retrieved from https://juntas.geledes.org.br/

Governo do Distrito Federal. (2017). Aplicativo viva flor. Retrieved from http:// www.brasilia.df.gov.br/aplicativo-viva-flor/

Grupo de Estudos em Prevenção e Promoção de Saúde no Ciclo de Vida. (n. d). SOS namoro. Retrieved from http://sosnamoro.geppsvida.com.br/

Harris, B., Dragiewicz, M., \& Woodlock, D. (2020). Technology, domestic violence advocacy and the sustainable development goals. In J. Blaustein, K. Fitz-Gibbon, N. W. Pino, \& R. White (Eds.), Emerald handbook of crime, justice and sustainable development (pp. 295-313). Bingley: Emerald Publishing Limited.

Harris, B., \& Woodlock, D. (2019). Digital coercive control: Insights from two landmark domestic violence studies. British Journal of Criminology, 59(3), 530-550. doi:10.1093/bjc/azy052 
Henry, N., McGlynn, C., Flynn, A., Johnston, K., Powell, A., \& Scott, A. J. (2020). Image-based sexual abuse: A study on the causes and consequences of non-consensual nude or sexual imagery. London, New York: Routledge.

Henry, N., Powell, A., \& Flynn, A. (2017). Not just 'revenge pornography': Australians' experiences of ImageBased abuse. A Summary Report. RMIT University, Melbourne.

Instituto Avon/Data Popular. (2014). Violência contra a mulher: o jovem está ligado?. Retrieved from https://dossies.agenciapatriciagalvao.org.br/dados-e-fontes/pesquisa/ violencia-contra-a-mulher-o-jovem-esta-ligado-data-popular-instituto-avon-2014/

King-Ries, A. (2011). Teens, technology, and cyberstalking: The domestic violence wave of the future? Texas Journal of Women and the Law, 20(2), 131-164. Retrieved from http://search.proquest.com/docview/902629166/

Mackenzie, C., \& Mackay, T. (2019). 'I just wanted to keep my boyfriend happy': Young country women's perceptions of intimate partner violence. Adelaide: The Australian Alliance for Social Enterprise. University of South Australia.

Microsoft News Center Brasil. (2020). Chatbot Maia é lançada para ajudar na conscientização de meninas sobre relacionamentos abusivos. Retrieved from https:// news.microsoft.com/pt-br/chatbot-maia-e-lancada-para-ajudar-na-conscientizacaode-meninas-sobre-relacionamentos-abusivos/

Minayo, M. S. C., Assis, S. G., \& Njaine, K. (2011). Amor e violência: Um paradoxo das relações de namoro e do'ficar' entre jovens brasileiros. doi:10.7476/9788575413852

Murta, S. G., de Oliveira Parada, P., da Silva Meneses, S., Medeiros, J. V. V., Balbino, A., Rodrigues, M. C., \& de Vries, H. (2020). Dating SOS: A systematic and theorybased development of a web-based tailored intervention to prevent dating violence among Brazilian youth. BMC Public Health, 20(1), 1-14.

Murta, S. G., dos Santos, B. R. P., Martins, C. P. S., \& de Oliveira, B. (2013). Prevenção primária à violência no namoro: Uma revisão de literatura. Contextos clínicos, 6(2), 117-131.

Murta, S. G., Pires, M. R. P., Tavares, A. S., Cordeiro, M. A., Teixeira, E. G., \& Adorno, N. (2019). Intimidade e apego no namoro: Implicações de estudos de caso para prevenção à violência. Contextos Clínicos, 12(1), 204-225.

Observatório da Mulher Contra a Violência, Instituto de Pesquisa DataSenadoSecretaria da Transparencia. (2018). Panorama da violência contra as mulheres no Brasil: Indicadores nacionais e estaduais. Retrieved from http://www.senado.gov.br/institucional/datasenado/omv/indicadores/relatorios/BR-2018.pdf

Office of the eSafety Commissioner. (2018). State of play: Youth, kids and digital dangers. Retrieved from https://www.esafety.gov.au/about-the-office/research-library

Oliveira, Q. B. M., Assis, S. G. d., Njaine, K., \& Oliveira, R. C. d. (2011). Violências nas relações afetivo-sexuais. In M. C. S. Minayo, S. G. Assis, \& K. Njaine (Eds.), Amor e violência: Um paradoxo das relações de namoro e do'ficar' entre jovens brasileiros (pp. 45-54). doi:10.7476/9788575413852

Our Watch. (2016). Final evaluation report: Technical appendix A - evaluation design and tools. Retrieved from https://www.ourwatch.org.au/getmedia/97ec4f00-e2774c17-ae48-553d7cae68bb/RRE_Technical-Appendices-A-Final.pdf.aspx

Our Watch. (2017). Primary prevention of family violence against people from LGBTI communities. Retrieved from https://www.ourwatch.org.au/resource/primary-prevention-of-family-violence-against-people-from-lgbtiq-communities-an-analysis-ofexisting-research 
Our Watch. (2018). Changing the picture: A national resource to support the prevention of violence against Aboriginal and Torres Strait Islander women and their children. Melbourne: Our Watch.

Pascua, R., Khokhar, B., Saeed, N., Uwineza, J., \& Taukolo, A. (2019). R4Respect. Respectful relationships peer education guide. Logan, Queensland: YFS Ltd.

Politoff, V., Crabbe, M., Honey, N., Mannix, S., Mickle, J., Morgan, \& Webster, K. (2019). Young Australians' attitudes to violence against women and gender equality: Findings from the 2017 National Community Attitudes towards Violence against Women Survey (NCAS) (ANROWS insights, issue 01/2019). Sydney: ANROWS.

Promundo. (n. d). Program H. Retrieved from https://promundoglobal.org/programs/ program-h/

Rodríguez Domínguez, C., Pérez-Moreno, P. J., \& Durán, M. (2020). Cyber dating violence: A review of its research methodology. Anales de Psicología, 36(2), 200-209.

Senior, K., Helmer, J., \& Chenhall, R. (2017). 'As long as he's coming home to me': Vulnerability, jealousy and violence in young people's relationships in remote, rural and regional Australia. Health Sociology Review, 26(2), 204-218.

Soares, J. D. S. F., Lopes, M. J. M., \& Njaine, K. (2013). Violência nos relacionamentos afetivo-sexuais entre adolescentes de Porto Alegre, Rio Grande do Sul, Brasil: Busca de ajuda e rede de apoio. Cadernos de Saúde Pública, 29, 1121-1130.

Stark, E. (2007). Coercive control: How men entrap women in personal life. New York, NY: Oxford University Press.

Straus, M. (2004). Cross-cultural reliability and validity of the revised conflict tactics scales: A study of university student dating couples in 17 nations. Cross-Cultural Research, 38(4), 407-432. doi:10.1177/1069397104269543

Struthers, K., Parmenter, N., \& Tilbury, C. (2019). Young people as agents of change in preventing violence against women. Research Report, 02/2019. ANROWS, Sydney, NSW.

Tarzia, L., Iyer, D., Thrower, E., \& Hegarty, K. (2017). “Technology doesn't judge you": Young Australian women's views on using the internet and Smartphones to address intimate partner violence. Journal of Technology in Human Services, 35(3), 199-218.

Taylor, A., Lauro, G., Murphy-Graham, E., Pacheco, T., Pacheco Montoya, D., \& Araújo, D. (2017). Adolescent relationship violence in Brazil and Honduras. Retrieved from https://promundoglobal.org/resources/adolescent-relationship-violence-brazilhonduras/?lang=english

Taylor, A. Y., Murphy-Graham, E., \& Lauro, G. (2019). Conceptualizing controlling behaviors in adolescent and youth intimate partner relationships. Partner abuse, 10(2), 137-163.

The Line. (2017). Tracking change: Snapshot evaluation findings for the line campaign 2015 to 2017. Retrieved from https://www.ourwatch.org.au/resource/trackingchange-snapshot-evaluation-findings-for-the-line-campaign-2015-to-2017/

UN Broadband Commission. (2015). Cyber violence against women and girls. Retrieved from https://www.unwomen.org/ /media/headquarters/attachments/sections/library/ publications/2015/cyber_violence_gender\%20report.pdf?v =1\&d=20150924T154259

UN General Assembly. (2018). Report of the Special Rapporteur on violence against women, its causes and consequences on online violence against women and girls from a human rights perspective. Retrieved from https://igitallibrary.un.org/ record $/ 1641160 ? \ln =$ en 


\section{Gisella Lopes Gomes Pinto Ferreira}

UNICEF. (2017). The state of the world's children 2017: Children in a digital world. Retrieved from https://www.unicef.org/publications/index_101992.html

UNICEF. (2019). Projeto Caretas. Retrieved from https://www.unicef.org/brazil/projeto-caretas

Viza, B., Sartori, M. C., \& Zanello, V. (Eds.). (2017). Maria da Penha vai à escola: Educar para prevenir e coibir a violência doméstica e familiar contra a mulher. Brasília: TJDFT. Retrieved from https://www.tjdft.jus.br/informacoes/cidadania/ centro-judiciario-mulher/documentos-e-links/e-book-maria-da-penha-vai-a-escola

Wilson, T. D. (2014). Violence against women in Latin America. Latin American Perspectives, 41(1), 3-18. doi:10.1177/0094582X13492143

Wolfe, D. A., Scott, K., Reitzel-Jaffe, D., Wekerle, C., Grasley, C., \& Straatman, A. L. (2001). Development and validation of the conflict in adolescent dating relationships inventory. Psychological Assessment, 13(2), 277-293.

Woodlock, D. (2017). The abuse of technology in domestic violence and stalking. Violence Against Women, 23(5), 584-602. 